W stużbie tradycji i odnowy liturgicznej. 50 lat Instytutu Liturgicznego w Krakowie (1968-2018), red. P. Nowakowski, J. Mieczkowski, Kraków 2019, s. 9-11.

ISBN 978-83-7438-849-8 (wersja drukowana), ISBN 978-83-7438-850-4 (wersja online) DOI:http://dx.doi.org/10.15633/9788374388504.02

bp Adam Bałabuch

Przewodniczący Komisji ds. Kultu Bożego i Dyscypliny Sakramentów KeP

POLSKA

\title{
Duch Święty przypomina i uobecnia
}

Kiedy przybliżył się moment odejścia Chrystusa z tego świata, zapowiedział On swoim uczniom przyjście Parakleta, Ducha Pocieszyciela, który miał ich wszystkiego nauczyć i przypomnieć apostołom wszystko, co Jezus im powiedział (por. J 14, 26).

Było to konieczne dla uczniów, gdyż czas ich wspólnego przebywania z Jezusem nie był zbyt długi. Sami apostołowie nie byli też w stanie zrozumieć wszystkiego, co mówił ich Mistrz. W związku z tym potrzebne było, by Chrystus po zmartwychwstaniu posłał swoim uczniom Ducha Prawdy, który miał ich doprowadzić do całej prawdy, do ostatecznego zrozumienia posłannictwa Jednorodzonego Syna.

Duch Święty, który zstąpił na apostołów, w pierwszym rzędzie dał świadectwo o Chrystusie. Przypomniał im wszystko, co Jezus powiedział i uczynił. Objawił im też prawdziwy sens zbawczych słów i czynów Chrystusa, który przekazał światu to, co widział i słyszał u Ojca.

Tym samym Duch Prawdy staje się po odejściu Chrystusa gwarantem, na którym Kościół buduje swoją pewność, że trwa niezawodnie w autentycznej nauce swojego Założyciela. Ten bowiem, który od Ojca i Syna został posłany, utwierdzał najpierw w prawdzie Bożej apostołów, a później również ich następców. Tak jest i dzisiaj, i tak będzie aż do końca świata. Duch Prawdy bowiem nieustannie świadczy o Chrystusie, to znaczy ukazuje 
prawdziwe znaczenia Ewangelii, by Kościół w swoim pielgrzymowaniu przez wieki nie pobłądził, ale zawsze miał światło prawdy.

Posłannictwo Ducha Prawdy obdarzone boską mocą nie ogranicza się jednak tylko do przypominania prawdy i ukazywania jej autentycznego sensu. Jak uczy bowiem ojciec św. Jan Paweł II w swojej katechezie z dnia 17 maja 1989 roku, „Duch Prawdy”, przypominając "słowa i czyny oraz całą zbawczą tajemnicę Chrystusa, uobecnia je stale w Kościele, sprawia, że stale są aktualne, a równocześnie przyoblekają się w aktualność Kościoła wspólnoty zbawienia. Dzięki działaniu Ducha Świętego Kościół nie tylko pamięta prawdę, ale trwa w prawdzie otrzymanej od swego Pana". Duch Święty sprawia zatem, że słowa i czyny Chrystusa, zwłaszcza Jego zbawcze dzieło, żyją we wspólnocie Kościoła i stają się dla nas obecne przede wszystkim w liturgii.

Liturgia powinna być przede wszystkim głęboką, duchową modlitwą. Uczestnictwo w liturgii nie może być dla nas zwykłą czynnością ale powinniśmy widzieć, uczestnicząc w liturgii, przede wszystkim Jezusa z całym Jego zbawczym dziełem. Za każdym razem, kiedy uczestniczymy w liturgii, powinniśmy też dziękować Jezusowi za wszystko, co uczynił dla nas. Powinniśmy również uświadomić sobie, jak bardzo Jezus nas kocha, i widzieć Chrystusa, który otwiera szeroko ramiona na krzyżu, aby nas objąć, który zmartwychwstaje, aby dać nam udział w swoim wiecznym życiu.

Za każdym razem, kiedy uczestniczymy w liturgii, powinniśmy ofiarować Jezusowi nasze cierpienia, ale też sukcesy i radości. Powinniśmy także patrzeć na naszego umierającego na krzyżu Pana, widząc, jak bardzo jesteśmy kochani, skoro Jezus oddał za nas życie.

Kiedy tak będziemy zawsze wchodzić w liturgię, doświadczymy, że jesteśmy obdarzani łaską i siłą potrzebną do uczciwego chrześcijańskiego życia, wypełnionego miłością i posłuszeństwem woli Bożej. Właściwe uczestnictwo w liturgii ma nas bowiem prowadzić do nowego życia.

Obecny rok liturgiczny przypomina nam, że ,jesteśmy napełnieni Duchem Świętym". Dlatego trzeba nam prosić Ducha Świętego o dar żywego i głębokiego uczestniczenia w liturgii. Jakże bardzo potrzebujemy pomocy Ducha Świętego, ponieważ sami z siebie jesteśmy słabi. Dlatego trzeba nam prosić Ducha Świętego: „Pomóż mi odpowiednio uczestniczyć w liturgii", a wówczas poprowadzi nas głębiej w spotkanie z Chrystusem, tak abyśmy, jak Maryja pod krzyżem, mogli samych siebie składać Bogu w ofierze. 

11

Jeżeli tak będziemy starali się uczestniczyć w liturgii, to będzie ona dla nas nie tyle obowiązkiem, lecz czymś radosnym, pełnym pokoju i miłości.

Zaczniemy również coraz bardziej odkrywać, jak każda nasza myśl, każde słowo, każdy czyn staje się modlitwą miłości zanoszoną do Boga. Zaczniemy dostrzegać miłość, którą każdego dnia na nowo ofiaruje nam Bóg. Wszędzie powoli zaczniemy widzieć dzieła Bożej miłości, które będą pobudzać nas do wdzięczności za cudowne Jego dary.

Podczas tej Eucharystii, która jest przecież dziękczynieniem, dziękujemy Panu Bogu za 50 lat Instytutu Liturgicznego w Krakowie, który pozostawał przez ten czas i pozostaje nadal w służbie tradycji i odnowy liturgicznej. Dziękujemy za wszystkich, którzy ten Instytut tworzyli i tworzą, i za cały wkład wnoszony w pogłębianie refleksji teologicznej dotyczącej liturgii.

Życzymy z okazji złotego jubileuszu dalszego rozwoju Instytutu Liturgicznego w Krakowie i pięknych osiągnięć w służbie tradycji i odnowy liturgicznej. 
